\title{
No limiar da aurora: itinerários de uma travessia ritualística e alquímica em a Cidade Sitiada.
}

\section{En el despertar de la aurora: itinerarios de una travesía ritualista y alquímica en la Cidade Sitiada.}

\section{In the Treshold of the Aurora: Itineraries of a Ritualistic and Alchemical in Cidade Sitiada.}

\begin{abstract}
Resumo
Trata-se de um estudo da obra A cidade sitiada, de Clarice Lispector, em diálogo com a antropologia (ritos de passagem), a alquimia segundo psicologia junguiana, em que se pretende analisar a personagem em seu processo de individuação, ou seja, de autoconhecimento. Procurou-se perceber que a personagem protagonista é marcada pela conjugação e estigma do verbo viver, isto é, esta passa por diversas fases e estágios no sentido de descobrir quem realmente é, pois está sempre em busca de sua identidade, que será construída com o desenvolvimento de sua história no romance. 0 procedimento narrativo adotado por Clarice Lispector nessa obra levou-nos ao conceito dos ritos de passagem teorizado por Arnold Van Gennep e a alquimia segundo Carl Gustav Jung. Investigaremos quais são os comportamentos exigidos à protagonista pelos outros membros da comunidade na qual se vê inserida, e de como esta se posiciona perante isso. Por fim, pretendemos demonstrar como a passagem dos ritos na vida de Lucrécia, além de estar relacionada com seu desenvolvimento natural (fases da vida adulta), está ligada principalmente ao modo como o texto é construído.
\end{abstract}

Palavras claves Clarice Lispector, A cidade sitiada, Individuação, Ritos de Passagem, Alquimia. 
CATEDRAl Tomada: Revista de crítica literaria latinoamericana / Journal of Latin American Literary Criticism No limiar da aurora: itinerários de uma travessia ritualística e alquímica em a Cidade Sitiada.

\title{
Resumen
}

Se trata de un estudio de la obra $A$ cidade sitiada, de Clarice Lispector, en diálogo con la antropología (ritos de paso), la alquimia segundo psicología jungiana en la que se pretende analizar el personaje en su proceso de individuación, o sea, de autoconocimiento de si mismo. Se buscó percibir que el personaje protagonista está marcado por la conjugación y estigma del verbo vivir, es decir, esta pasa por diversas fases y etapas con el fin de descubrir quién realmente es, pues está siempre en busca de su identidad, que se construida con el desarrollo de su historia en la novela. El procedimiento narrativo adoptado por Clarice Lispector, en esa obra nos llevó al concepto de los ritos de paso teorizadas por Arnold Van Gennep y la alquimia, segundo Carl Gustav Jung. Investigamos cuáles sonlos comportamientos exigidos a la protagonista por los otros miembros de la comunidad en la que ver insertada, y de cómo está se posiciona esta antes de ello. Por último, tenemos la intención de demostrar cómo el paso de los ritos en la vida de Lucrecia, además de estar relacionado a su desarrollo natural (fases de la edad adulta), está vinculada principalmente la forma como en que el texto es construido.

\section{Palabras claves Clarice Lispector, A cidade sitiada, Individuación, Ritos de Paso, Alquimia.}

\begin{abstract}
This is a study of the work $A$ cidade sitiada by Clarice Lispector, in dialogue with antropology (rites of passage), the second alchemy Jungian psychology in which it is intended to analyze the character in its individuation process, that means of self-knowledge of oneself. We perceived that the principal character is marked by the conjugation and stigma of the verb to live, that is, it goes through different phases and stages in order to discover who he really is, since he is always in search of his identity, which is constructed with the development of his story in the novel. The narrative procedure adopted by Clarice Lispector, in that work led us to the concept of the rites of passage theorized by Arnold Van Gennep and alchemy, second Carl Gustav Jung. We investigated which are the behaviors demanded from the protagonist by the other members of the community in which to see inserted, and how it is positioned before it. Finally, we intend to show how the passage of the rites in Lucrecia's life, in addition to being related to her natural development (phases of adulthood), is mainly linked to the way in which the text is constructed.
\end{abstract}

Keywords Clarice Lipespector, A cidade Sitiada, Individuation, Rites of Passage, Alchemy.

\section{O nascer de um novo dia: o ritual como experiência de transformação.}

O romance A cidade sitiada, de Clarice Lispector foi publicado em 1949, e, conforme a autora, foi seu livro mais difícil de escrever, uma vez que ansiava 
por algo e não sabia o que era. A partir dessa procura é que surge Lucrécia, personagem-protagonista, que vive uma busca incessante para conhecer a si mesma e isso ocorre essencialmente através dos binômios destruir/ construir, ligados também à cidade de São Geraldo que é sua própria representação.

A trajetória de Lucrécia em A cidade sitiada pode ser analisada pela teoria dos ritos de passagem e da alquimia, pois estes simbolizam o processo natural de descoberta da identidade e individuação da personagem. Contudo, ela necessita da presença do outro, a fim de se conhecer, bem como adquirir uma sabedoria que a fará experimentar outros estágios de seu ritual alquímico. Nesse processo de construção da identidade, ela vive diversos ritos, como por exemplo, os festivos em comemoração ao dia de São Geraldo, a morte do pai, os relacionamentos amorosos e o casamento com Mateus:

- Onze horas, disse Felipe.

Mal acabara de falar o relógio da igreja bateu a primeira badalada, dourada, solene. O povo pareceu ouvir um momento o espaço... o estandarte na mão de um anjo imobilizou-se estremecendo. Mas de súbito o fogo de artifício subiu e espocou entre as badaladas. A multidão, tocada do sono rápido em que sucumbira, moveu-se bruscamente e de novo rebentaram gritos no carrossel.

[...]Quando Felipe e Lucrécia alcançaram a roda-gigante o sino sacudiuse acima da noite enchendo de emoção a festa religiosa - o movimento da multidão tornou-se mais ansiado e mais livre. A população acorrera para celebrar o subúrbio e seu santo, e no escuro o pátio da igreja resplandecia. (Lispector 07)

Os ritos de passagem definem-se como cerimônias ou rituais que celebram a passagem de um indivíduo para uma nova forma de vida ou um novo status social. Sendo assim, os ritos são momentos especiais construídos pela sociedade, pois eles, “'fazem coisas', 'dizem coisas', 'revelam coisas', 'escondem coisas', 
CATEDRAL Tomada: Revista de crítica literaria latinoamericana / Journal of Latin American Literary Criticism No limiar da aurora: itinerários de uma travessia ritualística e alquímica em a Cidade Sitiada.

'provocam coisas', 'armazenam coisas"” (Damatta 71). O ritual possibilita, assim, “concentrar a atenção, na medida em que fornece um quadro, estimula a memória e liga a um passado pertinente. Facilita deste modo, a percepção" (Douglas 51), e pode-se dizer ainda que, "em cada um desses casos, se trata sempre de uma iniciação, pois envolve sempre uma mudança radical de regime ontológico e estatuto social" (Eliade 89).

Estudar a narrativa de $A$ cidade sitiada pelo viés do ritual e da alquimia possibilita ver o mundo social tomando como ponto de partida momentos importantes: o mundo cotidiano e as festas; a rotina e o ritual; a vida e a sociedade. "O ritual é algo plenamente compatível com o mundo da vida diária e os elementos da vida diária são os mesmos elementos do ritual” (Damatta 71).

Os ritos de passagem são cerimônias que existiram e existem em diversas culturas, antigas ou contemporâneas, seguindo cada transformação e mudança de lugar, idade, estado ou posição social dos indivíduos que os acompanham até a morte. Além disso, o rito se enquadra, conforme aponta DaMatta, "na sua coerência cênica grandiosa ou medíocre - aquilo que está aquém e além da repetição das coisas 'reais' e 'concretas' do mundo rotineiro" (en Gennep 10). Assim, observamos que o rito do mesmo modo, "sugere e insinua a esperança de todos os homens na sua inesgotável vontade de passar e ficar, de esconder e mostrar, de controlar e libertar, nesta constante transformação do mundo e de si mesmo que está inscrita no verbo viver em sociedade" (10).

Vale ressaltar que, conforme mencionado, teremos três ritos, estes sendo percebidos como universais, segundo Gennep (2011), isto é, ritos de separação, margem e agregação, em que os analisaremos em consonância com a alquimia, porém eles se apresentarão durante a análise do texto, assim que surgir algo que os relacione e os identifique na narrativa. Logo, poderá acontecer de enfatizarmos um em detrimento de outro, visto que estamos privilegiando os eventos em que se apresentarão no decorrer da narrativa.

Trabalharemos, pois, com a possibilidade do romance A cidade sitiada representar um ritual alquímico. Isso porque, como veremos no decorrer da 
análise do texto, os personagens são ritualísticos e, consequentemente, a história narrada surge enquanto ritual que se associa à memória, e, sobretudo mostra a protagonista, numa espécie de re-início, descreve-nos as experiências como se fossem a "primeira vez", um retorno constante ao centro, ao núcleo das coisas e Lucrécia ao executar os seus ritos de passagem experimenta a vida através da matéria e do mundo que a cerca. A alquimia entra nesse processo como forma de transmutação nos ritos, porque ao vivenciá-los, Lucrécia transforma a si mesma em contato com os elementos naturais como água, terra, fogo e ar, pois estes vistos enquanto símbolos compõem uma relação com o plano humano e divino.

Temos, assim, o processo ritual da protagonista Lucrécia e o modo como é descrito no texto literário:

Embora, enquanto olhasse, se passasse um tempo que um dia se chamaria de aperfeiçoamento? aqueles longos anos que se passavam através de momentos espalhados: através de raros instantes Lucrécia Neves possuía um só destino. Como era lenta, as coisas à força de serem fixadas ganhavam a própria forma com nitidez - era o que às vezes conseguia: atingir o próprio objeto.

E fascinar-se: porque eis a mesa no escuro. Elevada acima de si mesma pela sua falta de função. As outras coisas da sala ingurgitadas pela própria existência, enquanto o que pelo menos não era maciço, como a mesinha oca de três pernas - não possuía, não dava - era transitório surpreendente - pousado - extremo. (Lispector 67)

Observamos a relação apresentada pelo narrador quando utiliza do objeto para demonstrar como os ritos atuam na vida e história da protagonista, ou seja, o rito é transitório, ele possui três tipos principais segundo Arnold Van Gennep, ritos de separação podemos associá-lo com a palavra "surpreendente" utilizado pelo narrador na descrição da mesa, ritos de margem ou liminar, ligado ao vocábulo "pousado" e ritos de agregação, equiparado à palavra "extremo". 
CATEDRAL TOMADA: Revista de crítica literaria latinoamericana / Journal of Latin American Literary Criticism No limiar da aurora: itinerários de uma travessia ritualística e alquímica em a Cidade Sitiada.

Lucrécia vivencia os ritos de passagem através do olhar e este fica cada vez mais nítido a medida que vai se aperfeiçoando diante das coisas vivenciadas.

A teoria dos ritos de passagem e da alquimia servir-nos-á como aparato teórico-metodológico para a análise da obra e assinala as mudanças dos indivíduos em diferentes estágios. Van Gennep estuda como as sociedades realizam seus ritos, e nos mostra como a passagem de uma categoria, ou condição a outra demarca como esses ritos podem ser concebidos em sequenciação narrativa ou sequência cerimonial, bem como podemos situá-los numa relação trifásica, a saber:

No caso dos ritos preliminares (ritos de separação), há um movimento de ruptura na organização primeira. Provas e provações serão vistas enquanto resultado da separação do indivíduo do grupo no qual estava inserido.

Em seguida, temos os ritos liminares (ritos de margem), surge na liminaridade do processo, ou seja, o indivíduo está na margem entre a sua vida antiga e a que está por surgir, dessa maneira vivendo nesse estágio, este experimenta tanto o aspecto sagrado quanto o profano da vida, a fim de passar pelas transformações naturais desse processo.

Os ritos pós-liminares (ritos de agregação), surgem a partir de uma nova organização do sistema atrelada ao que veio anteriormente. Demonstra a passagem do indivíduo pelas provas das fases anteriores, o que mostra que este está apto e habilitado a ser um membro dessa comunidade, pois cumpriu todo o ritual esperado.

Além dos ritos de passagem, necessitamos conhecer, essencialmente, como se configura a alquimia. Seu objetivo é obter, da transformação da matériaprima, a substância miraculosa, ou seja, transformar o vil metal num metal precioso, cujo símbolo mais conhecido é a Pedra Filosofal. Por este motivo, o alquimista necessitava antes descobrir o material ideal, isto é, a matéria-prima, que era submetida a várias operações, as quais a tornava purificada e a transformaria na Pedra Filosofal.

Para Mircea Eliade, a alquimia se define como 
[...] o drama místico do Deus, sua paixão, sua morte, sua ressurreição o que se projeta sobre a matéria para transmutá-la. Em definitivo, o alquimista trata à Matéria como o Deus era tratado nos Mistérios; as substâncias minerais "sofrem", "morrem", "renascem" a um novo modo de ser; quer dizer, são transmutadas. (120)

Essas transformações contínuas na matéria, no corpo e no espírito sempre impressionaram o homem. Por isso, este frequentemente procurou investigar esses fenômenos através do conhecimento espiritual e dos experimentos com a matéria. Dessa tentativa de formar um conhecimento sobre a natureza é que nasceu a Alquimia.

O processo alquímico representa a procura do estado original da matéria que passou por uma transformação, ou seja, a transmutação do vil metal em ouro. E é nesse ritual de transformação que investigamos a alquimia em A cidade sitiada, sob a perspectiva dos estudos de Carl Gustav Jung e do Edward Edinger. Durante o processo alquímico, a matéria-prima passa por operações, a saber: calcinatio, solutio, coagulatio, sublimatio, mortificatio, separatio e coniunctio. Estas operações estão intimamente relacionadas com os quatro elementos da natureza: água, terra, ar e fogo. Vale lembrar que os preceitos alquímicos se referem ao modo pelo qual os rituais alquímicos se constituem, bem como ganham forma e desenvolvimento, principalmente atrelados à análise do texto.

A alquimia pressupõe uma ordem de conhecimento que se apresenta na trasmutação iniciática da consciência humana. Estudar suas imagens, conforme observaremos nas diversas operações alquímicas, equivale a descrever o processo de autoconhecimento. A imagem central da alquimia é a idéia de opus. Para o alquimista, o seu trabalho era visto como algo sagrado e solitário e pelo qual ele denotava um valor supremo e essencial. Além disso, certas virtudes eram requisitos primordiais, como possuir uma alma paciente, laboriosa e solícita vinculada à coragem perseverante e a dedicação contínua. 
CATEDRAL Tomada: Revista de crítica literaria latinoamericana / Journal of Latin American Literary Criticism No limiar da aurora: itinerários de uma travessia ritualística e alquímica em a Cidade Sitiada.

O surgimento da prima materia possui sua história ligada à antiga filosofia. Os filósofos pré-socráticos tinham uma ideia de que o mundo foi criado advindo de uma matéria primeira, única e original. Essa mesma matéria passava por um processo que a diferenciava e a decompunha nos quatro elementos, a saber: água, fogo, ar e terra, qualificados sequencialmente em úmido, quente, frio e seco. Os alquimistas pensavam que era preciso, antes de tudo, fazer a matéria retornar ao seu estágio inicial e original.

Para alguns alquimistas, a busca pela Pedra Filosofal era metáfora da mutação da alma do próprio alquimista camuflada por fórmulas químicas e simbologias complexas. A Pedra Filosofal, para esses alquimistas, seria o símbolo de uma sabedoria que o homem adquire com o tempo e com a prática da alquimia. A partir dessa sabedoria, o alquimista poderia chegar a uma nova visão do mundo e a um domínio maior sobre a matéria. Pensando assim, a transmutação da matéria pode ser entendida como um símbolo de mudança profunda que ilumina, quer dizer, que transforma o interior do alquimista em ouro.

Assim, ao explorar a matéria em seu aspecto químico, o alquimista também fazia suas próprias experiências, encontrava a sua substância viva, visto que sua transformação inconsciente era um produto particular desse processo químico. O fato é que, em seu laboratório, ele já estava experienciando o seu próprio inconsciente.

É importante dizer que, em todas essas etapas, a alquimia na vida de Lucrécia se faz presente, visto que indica um momento de transformação do indivíduo quando este experimenta a matéria com o intuito de buscar constituir sua identidade e completar seu processo de individuação. Para tanto, reforçamos nossa investigação quanto a relação que se é estabelecida entre ritos de passagem e alquimia na presente narrativa, bem como nomearemos tal processo como sendo ritual-alquímico, ou seja, fases que ocorrem na vida da protagonista e a faz encontrar consigo e se identificar com os elementos que a compõem.

Nessa mesma perspectiva, deparamo-nos com esse processo trifásico que se relaciona à vida da protagonista desde a fase de mulher solteira à casada. É o 
que apresentaremos e analisaremos a seguir. Vale ressaltar que esse processo será investigado na medida em que surjam essas transformações e mudanças na narrativa, em especial na vida de Lucrécia.

\section{Sombra e luz: o espaço do ritual e da alquimia}

A narrativa de $A$ cidade sitiada já se inicia com a celebração de um rito voltado para a cerimônia religiosa, a festa de São Geraldo, lembrando que a cidade possui o mesmo nome. Os ritos populares têm como propósito promover o encontro entre as pessoas e, por isso, nesse momento acontece a união entre Lucrécia e Felipe.

- Onze horas, disse Felipe.

Mal acabara de falar o relógio da igreja bateu a primeira badalada, dourada, solene. O povo pareceu ouvir um momento o espaço... o estandarte na mão de um anjo imobilizou-se estremecendo. Mas de súbito o fogo de artifício subiu e espocou entre as badaladas. A multidão, tocada do sono rápido em que sucumbira, moveu-se bruscamente e de novo rebentaram gritos no carrossel.

[...]Quando Felipe e Lucrécia alcançaram a roda-gigante o sino sacudiuse acima da noite enchendo de emoção a festa religiosa - o movimento da multidão tornou-se mais ansiado e mais livre. A população acorrera para celebrar o subúrbio e seu santo, e no escuro o pátio da igreja resplandecia. (Lispector 07)

Em meio à celebração religiosa percebemos o rito de agregação e a coniunctio de Lucrécia e Felipe se instaurando. Isso porque além de viverem esse ritual festivo e tradicional junto à comunidade, eles celebram esse encontro que se apresenta no escuro da noite, pois somente os fogos de artifício é que os 
CATEDRAL Tomada: Revista de crítica literaria latinoamericana / Journal of Latin American Literary Criticism No limiar da aurora: itinerários de uma travessia ritualística e alquímica em a Cidade Sitiada.

iluminavam nesse instante. As badaladas do relógio interrompem todo acontecimento vivido pelos personagens na cidade de São Geraldo e anunciam a descida aos infernos, segundo os preceitos alquímicos, ao mundo da escuridão, assinalando momentos de alternância entre escuridão e luz, destruição e construção. O cenário citadino é sombrio, pois percebemos que tudo ocorre às onze horas, ou seja, é o horário antecedente à meia-noite. Indica o momento máximo em que as trevas se ascendem antes do retorno da luz solar. É nesse instante que as mudanças ocorrem, porém às cegas para os homens, pois é a hora de dormir, e para o criador é onde a natureza se transforma.

Lucrécia conhece através da escuridão como se efetuam os ritos de passagem, pois viver o desconhecido traz para ela uma sensação de “desorganização profunda” da vida. O seu processo é transitório, ela experimenta aquilo que o ritual alquímico lhe apresenta e através deste adquire sabedoria para prosseguir em sua trajetória diária. "De novo arrastada por Felipe, ambos agora seguiam uma direção desconhecida através do povo [...]. Seu rosto queria avançar, mas seu corpo mal pôde mover-se porque a festa repentinamente se comprimira, perpassada por uma contração inicial longínqua" (Lispector 08).

Dentro desse contexto de trevas e escuridão, temos a nigredo (negrura) que está vinculada no processo do ritual alquímico à transformação e, no caso da protagonista experimentar essa fase é algo fundamental, a fim de que ela siga em direção e encontro de sua luz, de si mesma.

Noutro momento, encontramos o fogo, que na alquimia é um símbolo da calcinatio, visto enquanto elemento transformador dentro dos ritos de agregação e coniunctio do casal de personagens.

Uma vez junto do fogo, paravam e espiavam avermelhadas. As flamas apuravam os gestos, as enormes cabeças se mexiam mecanicamente, suaves. [...] Sob o chapéu o rosto iluminado de Lucrécia ora se tornava delicado, ora monstruoso. Ela espiava. A cara tinha uma atenção doce, 
sem malícia, os olhos escuros espiando as mutações do fogo, o chapéu com a flor. (Lispector 08)

No ritual alquímico da protagonista, o fogo que queima é o mesmo fogo que purifica. Lucrécia reconhece essa dicotomia a partir do contato que tem com o outro e com a cidade, que é a sua representação, o seu modo de ser, pois, "a glória de uma pessoa era ter uma cidade" (95).

Alcançar a consciência e a revelação de si mesma está intimamente ligada ao processo de individuação e constituição da identidade da protagonista, porque será necessário que ela percorra todas as etapas ao longo de sua caminhada, o que assinala uma tarefa árdua que segue até o final da vida. E ao viver o seu ritual alquímico, em especial associado ao elemento fogo (calcinatio) temos que,

o conflito gera o fogo dos afetos e emoções e como todo fogo, este também tem dois aspectos, ou seja, o da convulsão e o da geração da luz. A emoção é por um lado o fogo alquímico, cujo calor traz tudo à existência e queima todo o supérfluo [omnes superfluitatescomburit]. Por outro lado, a emoção é aquele momento em que o aço ao golpear a pedra produz uma faísca: emoção é a fonte principal de toda tomada de consciência. Não há transformação de escuridão em luz, nem de inércia em movimento sem emoção. (Jung 105)

A emoção de Lucrécia advém da cidade de São Geraldo, a sua visão diante desse local é de transformação e mudança. O fogo da transformação da cidade é o mesmo fogo que emana do interior da protagonista.

Lucrécia entende que o momento presente é sempre uma atualização do que já viveu, "que atualidade! Que atualidade, via ela lançada no que estava acontecendo. Olhava em torno com a avidez, que atualidade!" (Lispector 37). A reflexão e análise das coisas que a rodeiam acontece através do olhar que é o espelho para a protagonista, pois, "no espelho sua elegância tinha a qualidade 
CATEdral TomadA: Revista de crítica literaria latinoamericana / Journal of Latin American Literary Criticism No limiar da aurora: itinerários de uma travessia ritualística e alquímica em a Cidade Sitiada.

falível das coisas belas demais sem raiz... numa emoção rápida ela bateu a porta do quarto, gritou com voz de súbito trágica e rompida: mamãe vou sair!” (36).

A visão que Lucrécia tem das coisas é algo que transcende o seu corpo, se relaciona, pois com a sua alma, e, esta, por sua vez, está ligada à natureza. "O vento a recebeu na rua, a moça parou protegendo os olhos feridos pela luz. E de súbito a claridade a revelou" (Lispector 36). A presença da luz indica revelação, epifania, o que torna esse momento solene e especial para a protagonista.

Para Marilena Chauí, em seu texto "Janela da alma, espelho do mundo", quem olha, olha de algum lugar, pois aquele que observa do alto e de longe possui um olhar vigilante, protetor, informante e mensageiro. Em outras palavras, sua prática não é apenas vigiar e espiar, mas vai, além disso, significa, ainda, refletir, ponderar, considerar e julgar, tornando-se, portanto, aquele que observa e reflete, situando-se no alto. Logo, este é um traço pertinente em nossa análise, especialmente direcionado à protagonista, pois ela se situa nesse patamar ascendente, olhando do morro de S. Geraldo, e este expressa o seu lugar de proteção e abrigo, estando localizado num horizonte distante.

Os dissabores que, necessariamente, Lucrécia encontrará pelo caminho representam uma palavra incompreensível, um comportamento incomum, tudo isso, ferem-na violentamente, mas por alguns instantes. Eles a deixam mais lisa e dura como uma pedra, sempre pronta para seguir sua caminhada em direção a outros lugares.

Não pertencer a nenhum lugar, nenhum tempo, nenhum amor. A origem perdida, o enraizamento possível, a memória imergente, o presente em suspenso. $\mathrm{O}$ espaço do estrangeiro é um trem em marcha, um avião em pleno ar, a própria transição que exclui a parada. Pontos de referência, nada mais. O seu tempo? O de uma ressurreição que se lembra da morte e do antes, mas perde a glória do estar além: somente a impressão de um sursis, de ter escapado. (Kristeva 15) 
Lucrécia está sempre pronta para fugir, pois nenhum obstáculo a retém e todas as intempéries e sofrimentos lhe são indiferentes na busca desse território invisível e prometido, dessa cidade que não existe, mas ela traz consigo em seu sonho e que deve ser chamado de um além. Ela é adepta da solidão, mesmo estando junto de alguém, ela é fiel a uma sombra, um segredo mágico, uma ambição inacessível. Lucrécia vive através do olhar sua paixão de agarrar-se altivamente ao que lhe falta, à ausência, a qualquer símbolo e objeto.

O estrangeiro está em nós. E quando fugimos ou tentamos combater o estrangeiro, estamos lutando contra o inconsciente. $\mathrm{O}$ sobrenatural seria assim a via real do outro no coração desse "nós-mesmos", que se revela como um “estranho país de fronteiras e de alteridades" incessantemente construídas e desconstruídas. A protagonista relata como essa experiência sobrenatural acontece, principalmente quando ela diz que "o espírito liberto juntara-se ao vento pela janela aberta? e cada vez mais nítida, ela era um objeto da sala: os pés apoiavam-se no assoalho [...]. E de ter os olhos feridos pelo brilho duro de seu pequeno anel no dedo, cuja pedra reunia em si a força da sala" (Lispector 113).

Lucrécia está à procura do centro do subúrbio. Isso porque é neste local que está o núcleo de si mesma, no entanto, mais uma vez:

o relógio da igreja abalou-se mais potente, misturando-se à delicadeza das outras horas. Lucrécia inquietou-se. Em breve, o tenente mal conseguindo acompanhá-la, a moça caminhava à frente quase correndo. O principal acontecimento da noite de S. Geraldo não fora sequer anunciado, a cidadezinha estava milagrosamente inteira ainda - Felipe ria irritado: não corra, menina! Dobraram a esquina e encontraram-se no largo da pedra. A torre do relógio ainda estremecia. (9)

A partir de então, a protagonista estava em busca de chegar ao íntimo de si mesma, porém no horário noturno encontramos o conhecimento divino atuando, o que sinaliza um momento de parada para os homens e o processo de inconsciência 
surge, estando ligado ao sonho. Por isso, a reação de Lucrécia em estar diante do "segredo do mundo" era de medo e sua atitude é de fugir para sua casa. Ela acreditava que descumprir essa ordem teria alguma punição. "A praça estava nua. Tão irreconhecível ao luar que a moça não se reconhecia. Também Felipe estacara aliviado, malditos! [...] Sábado era noite de vários mundos [...]” (9).

O desejo de Lucrécia em conhecer os mistérios da noite revela que o simbolismo do "regresso ao ventre" está ligado ao aspecto cosmogônico. Isso porque "é o mundo inteiro que, simbolicamente, regressa com o neófito à Noite cósmica para poder ser criado de novo, regenerado" (Eliade 94).

Ainda segundo Eliade,

o paciente é convidado a descer muito profundamente em si mesmo, a fazer reviver seu passado, enfrentar de novo seus traumatismos - e, do ponto de vista formal, essa operação perigosa assemelha-se ás descidas iniciáticas aos "Infernos", entre os espectros, e aos combates com os "monstros". Assim, como o iniciado devia sair vitoriosamente das provas, em suma, "morrer" e "ressuscitar" para alcançar uma existência plenamente responsável e aberta aos valores espirituais, o analisado de nossos dias deve afrontar seu próprio “inconsciente", assediado de espectros e monstros, para encontrar nisso a saúde e a integridade psíquicas, o mundo dos valores culturais. (100)

A partir desse contato da protagonista com a experiência de morte e vida, a cidade de São Geraldo progride e essa transformação se mostrava inexprimível para os seus habitantes. Isso acontece devido a uma nota de jornal em que tinha como título "O Crime do Cavalo num Subúrbio", o que nos sugere que a população sabia de algo que não deveria ser exposto. De acordo com isso, o aparecimento do cavalo em certosmomentos da narrativa traduz como sendo o filho da noite e do mistério e o seu significado está vinculado aos elementos alquímicos do fogo e da água. 
A imagem do cavalo, sobretudo, está ligada às trevas, ao inconsciente e simbolicamente o animal pode surgir galopando das entranhas da terra ou dos abismos do mar. Contudo, há várias passagens no texto que comprovam essa ideia: “[...] os moradores olhavam com rancor e admiração os grandes animais que invadem em trote a cidade rasa" (Lispector 13). Noutra cena, o narrador descreve o que acontece com a protagonista ao ver os cavalos: "Que realidade via a moça. [...] Mas de repente, no silêncio do sol, uma parelha de cavalos desembocou de uma esquina. Por um momento imobilizou-se de patas erguidas. [...] Reativada Lucrécia entrou no armazém" (14).

Vale a pena mencionar que o símbolo do cavalo pode representar para ela, a imagem do pai morto. Isso porque este sempre surge para protegê-la e ajudá-la durante a execução de seus ritos. Ela superará esse momento quando estiver na ilha, encontrando em outro homem o seu alento e proteção.

Do mesmo modo, Perseu também se une a protagonista trazendo a luz para iluminar o seu caminho na escuridão: "Não importava que na luz ele fosse tão cego como os outros na escuridão. À diferença é que ele estava na luz. 'Flutuantes', falou. [...]. Era essa a natureza de uma raça de homem”' (27-28).

Lucrécia vivendo seu lado consciente e inconsciente, em especial associado à imagem do cavalo, vivencia um outro símbolo, que se trata do sol. Este ilumina e aquece o "coração" da protagonista mesmo ela estando nas trevas, no mundo da inconsciência, pois ele é sinônimo de vida e calor:

[...] quando o sol ia se pôr, o ouro se espalhou pelas nuvens e pelas pedras. Os rostos dos habitantes ficaram dourados como armaduras e assim brilhavam os cabelos desfeitos. [...] Nesse ouro pálido à brisa havia uma ascensão de espada desembainhada - assim se erguia a estátua da praça. Passando pelas ruas mais leves os homens na luz pareciam vir do horizonte e não do trabalho. O subúrbio de carvão e ferro transportara-se para o alto da colina, os ramos das amendoeiras se balançavam. (Lispector 14) 
CATEDRAl TomadA: Revista de crítica literaria latinoamericana / Journal of Latin American Literary Criticism No limiar da aurora: itinerários de uma travessia ritualística e alquímica em a Cidade Sitiada.

O sol na alquimia significa o ouro. "O sol é o corpo celeste como possuidor de uma radiação de efeito mágico e transformante” (Jung 89). Assim, "não apenas o sol, mas também o homem, especialmente o iluminado ou o adepto é capaz de produzir o ouro em virtude dessa força universal” (91). A protagonista vivencia o sol que a ilumina e que está ligada aos seus ritos de passagem, porque em seu trajeto diário a imagem do "arcano solar" representa os ciclos naturais da vida e em sua potência criativa revela o princípio de organização e de continuidade, o desejo de renovação da vida.

Com efeito, o sol representa a visão sagaz, mágica e transformadora de Lucrécia quando olha a cidade, os objetos, o mundo. $\mathrm{O}$ eu que vê possui uma luz que irradia o seu campo de conhecimento, de consciência, mas na fonte da luz existe também escuridão, a presença da sombra. Por fora Lucrécia vê a luz, por dentro à escuridão, porque sua busca é o encontro consigo mesma. Sendo assim, a partir da visão das coisas criadas e vivendo a experiência de seu ritual alquímico é que ela compreende que "isto é o mundo e isto sou eu". Percebemos em Jung uma definição para esse momento ambivalente da personagem:

Era o primeiro dia do mundo, o primeiro raiar do sol após a escuridão primordial, quando aquele complexo capaz de ter consciência, o filho da escuridão, o eu capaz de conhecer, fez a distinção entre o sujeito e o objeto de um ser determinado, pois foi ele quem deu ao mundo e a si mesmo a voz e o nome. (Jung 104)

Em A cidade sitiada, Lucrécia busca através do olhar viver uma experiência de integração de si mesma. E para isso, temos na narrativa a personagem Efigênia, que nos é apresentada "no limiar da aurora, quando todos dormiam e a luz do mal se separa da umidade das árvores - no limiar da aurora o ponto mais alto da cidade passava a ser Efigênia" (Lispector 24). A guardiã de 
São Geraldo tinha o poder de ver a transformação da natureza na madrugada enquanto os homens estavam dormindo.

Efigênia em sua trajetória de vida sempre esteve em contato com o plano divino. Isso acontece devido a sua estadia num convento, bem como sua prática e devoção religiosa constantes, mas ela sente na sua própria "carne" uma lei que contradiz a lei do espírito, ou seja, o que era o seu espírito ela ignorava. E a partir dessa descoberta toda a natureza se rebelava e a experiência do ritual-alquímico era latente:

Eis porém que uma folha vibrava em aço no meio da ramagem escura como sinal para poder ser vista. Efigênia se levantava com esforço, recuperava a forma seca e entrava na cozinha. As panelas estavam frias, e o fogão morto. Em breve a chama se erguia, a fumaça enchia o compartimento e a mulher tossia com os olhos cheios de lágrimas. Enxugando-os, abrindo a porta dos fundos e cuspindo.

A terra do quintal estava dura. No espaço o arame de estender roupa. Efigênia esfregava as mãos esquentando-as: tudo aquilo estava para ser transformado pelo seu olhar. Um olhar que não vinha dos olhos mas da cara de pedra - era assim que os outros a viam e sabiam ser inútil lamentar-se. Diante daquele rosto eles deviam esconder a fraqueza, mostrar-se rude e não esperar louvor - era desse modo que Efigênia era boa e sem piedade. Voltava para a cozinha, tomava vários goles de café soprando, tossindo, cuspindo, enchendo-se do primeiro calor. Então abria a porta e a fumaça se libertava. De pé na soleira da porta, sem súplica, sem perdão. (Lispector 25-26)

Efigênia já vivencia o ritual alquímico em sua vida, sua experiência apresenta-se agregada à sabedoria adquirida diante das fases ritualísticas vividas, visto que sua relação com a matéria se transmutou e o seu processo de 
CATEDRAL TOMADA: Revista de crítica literaria latinoamericana / Journal of Latin American Literary Criticism No limiar da aurora: itinerários de uma travessia ritualística e alquímica em a Cidade Sitiada.

individuação e a sua integração é sinalizada pelo momento de náusea que a acomete, com o objetivo de "expelir" aquilo que a atormentava.

Eis a claridade neutra cobrindo a campina. Pássaros escuros voavam. Toda a ramagem estava transpassada de luz, de gravidade e perfume, A mulher cuspia longe com mais segurança, as mãos na cintura. Sua dureza de jóia. [...] Ela cuspia de novo, ríspida, feliz. O trabalho de seu espírito tinha sido feito: era dia. (26)

Continuando sua peregrinação pelos ritos de passagem e, principalmente por ter vivido com Felipe o ritual de agregação e, a partir de então, Lucrécia vive o estágio do rito de separação, afinal, ele sendo tenente tem como propósito obedecer às normas impostas pelo regimento militar, diferentemente do que ela almeja, pois com o olhar construía e destruía as coisas ao seu redor. Outro motivo de separação entre eles se deve ao tenente Felipe também menosprezar os costumes, as festas, os rios e cheiros da cidade de São Geraldo. A protagonista segue em direção a uma nova história de vida. No segundo capítulo intitulado "o cidadão", Perseu é outro homem que aparece na sua vida e será com ele que conhecerá o quão profundo é o poder da criação, vivendo mais uma vez o rito de agregação, afinal, ele era o símbolo do cidadão de São Geraldo.

O nome Perseu remete a uma figura mitológica que, quando nasceu, foi jogado ao mar estando aprisionado num cofre de ouro. Salvo, ele tornou-se depois herói, especialmente quando cortou a cabeça de Medusa, de cujo sangue nasceu Pégaso, o cavalo voador. Perseu é um gentil guerreiro, sempre pronto a ajudar sua dama. Vale ressaltar que, o motivo pelo qual Medusa é decapitada por Perseu está no poder que ela possui em transformar suas vítimas em pedra quando estas as olhavam em seus olhos.

Perseu, personagem de A cidade sitiada quer tomar para si o poder de petrificar, de conservar todas as coisas ao seu redor, porque "era o corpo existindo - sua concretização era luminosa: ele estava imóvel diante de uma janela" 
(Lispector 28). Por isso, sua intenção em atirar incessantemente as sementes pela janela, está na possibilidade de espalhar e criar raízes no que restou do antigo São Geraldo. Com efeito, Perseu nos é apresentado na narrativa numa tarde de 15 de maio de $192 \ldots$, tendo um traço componente do subúrbio, sendo então um de seus "alicerçadores", visto que nasceu quando a cidade se erguia, afinal, essa era a "natureza da raça humana".

A relação anunciada entre Perseu e Lucrécia se revela enquanto um esforço permanente, sendo, portanto, um modo de ser de São Geraldo, ou seja, destruição do antigo e surgimento do novo, um rito de iniciação sucessiva em que sujeito e objeto estão imersos no processo.

Perseu é apresentado na narrativa como "cego e glorioso - era isso apenas o que podia saber dele vendo-o à janela de um segundo andar. Porque este era o seu grau de luz" (27). Seu comportamento é de possuir uma ideia e não saber pensá-la, então, ele a expunha. O que o personagem lê revela a natureza de seu ser: "os seres marinhos quando não tocam o fundo do mar, se adaptam a uma nova vida flutuante ou pelágica" (27). Ele vive essa dicotomia do ser flutuante e pelágico, o que podemos relacionar aos símbolos do ar (sublimatio) e da água (solutio). Observamos que esses elementos alquímicos simbolizam no caso de Perseu um animal marinho que vive em constante processo de reprodução e que possui grandes asas imóveis. A esse simbolismo soma-se na cena que se segue a de uma gralha que voa assustada, "Perseu balançou os dois últimos caroços na concha da mão e lançou-os em dados. O jogo estava feito! Era de tarde. O rapaz parou maravilhado e vazio. Inesperadamente abriu as grandes asas num bocejo da juventude" (Lispector 30).

A relação amorosa entre Lucrécia e Perseu não progride, "ele bem a queria [...] ela lhe era necessária assim como a moça parecia precisar de móveis, de bibelôs; ele precisava dela para que ela concretizasse alguma coisa com sua presença?" (111). O que a protagonista deseja de Perseu é encontrar nele aquilo que para ela continua sendo uma lacuna. Ele classifica a postura dela sendo fugitiva, pois o seu desejo é de sempre experimentar situações novas e 
CATEDRAL Tomada: Revista de crítica literaria latinoamericana / Journal of Latin American Literary Criticism No limiar da aurora: itinerários de uma travessia ritualística e alquímica em a Cidade Sitiada.

desconhecidas. "Enquanto Lucrécia reinava olhando as unhas. Um dia ele tocaralhe os ombros para mostrar-lhe alguma coisa e sentira os ossos daquela que se julgava uma rainha..." (111). Porém, Perseu fica admirado com a afirmação de Lucrécia: "nós não vamos casar, mas somos como noivos" (112). A partir de então, ela utiliza a metáfora do papel, em especial quando diz que sua mãe havia cortado o dedo: "- Com papel... Era papel fino. Deu um talho que a carne nem pulou. Só riscou e saiu sangue" (113). Depois de ter mencionado a Perseu sobre o episódio ocorrido com a mãe ele decide ir embora.

É importante destacar que, “os ritos de separação compreendem, em geral, todos aqueles nos quais se corta alguma coisa, principalmente o primeiro corte de cabelos, o ato de raspar a cabeça, e mais o rito de se vestir pela primeira vez" (Gennep 63).

A partida de Perseu trouxe a Lucrécia um momento de reflexão, pois vivendo o seu rito de margem, ou seja, a personagem está no período liminar entre a sua vida antiga e a que está por surgir, dessa maneira vivendo nesse estágio, ela experimenta tanto o aspecto sagrado quanto o profano da vida, a fim de passar pelas transformações naturais desse processo. "O espírito liberto juntara-se ao vento pela janela aberta? e cada vez mais nítida, ela era um objeto da sala: os pés apoiavam-se no assoalho, o corpo se revelava no sexo e na forma" (Lispector 113).

Em se tratando de rito de margem, entendemos como um período ritual no qual é promovida a transição de um estágio individual ou coletivo para outro, bem como há uma transposição entre os estágios, os sujeitos rituais, estando no período marginal, dispensam algum tempo numa interestrutura, nomeada também de liminar. O indivíduo não estaria nem na estrutura anterior (rito de separação), nem na seguinte (rito de agregação) a que foi promovido.

O período de margem da personagem é uma composição de seu ritual alquímico e compreende que em sua jornada de experimentação da realidade da vida a máxima era possuir "uma paciência de construir e de demolir e de construir de novo e de saber que poderia morrer um dia exatamente quando demolira em 
vias de erguer" (Lispector 66). Nas palavras de Gennep, “qualquer pessoa que passe de um para outro acha-se assim, material e mágico-religiosamente, durante um tempo mais ou menos longo em uma situação especial, uma vez que flutua entre dois mundos" (35). Em suma, Gennep define esse momento como sendo o rito de margem, em que se faz necessário que o indivíduo passe por todas as cerimônias que acompanham a passagem de uma situação mágico-religiosa ou social para outra.

Outra situação em que a personagem executa o seu estágio liminar acontece quando "na posição em que estava, Lucrécia Neves poderia ser transportada à praça pública. Faltavam-lhe apenas o sol e a chuva. Para que, coberta de limo, fosse enfim desapercebida pelos habitantes e enfim vista diariamente com inconsciência" (76). Lucrécia associada à estátua revela que nesse momento de parada (ritos de margem) a realidade era de ver a cidade com os olhos de uma estrangeira diante do desconhecido e a menção aos símbolos do sol e da chuva indica que algo irá se transformar, "e se nada se transformara, a noite já perdera a sua data, e cheirava a cal úmida” (68).

Para a alquimia, a estátua representa um papel misterioso. Isso porque num antigo tratado grego, que trata de uma instrução dada por Komarius a Cleópatra, percebemos o seguinte:

depois de o corpo ter estado escondido nas trevas (o espírito) o encontrou repleto de luz. E a alma se uniu a ele, depois que ele se tornou divino pelo relacionamento com ela, e ele reside nela. Pois ele se vestiu de luz da divindade e as trevas se afastaram dele, e todos eles se uniram no amor, o corpo, a alma e o espírito, e eles se tornaram uma só coisa na qual está oculto o mistério. No ato deles se unirem completou-se o mistério e a casa foi selada, e foi erigida a estátua, repleta de luz e da deidade. (Jung 144) 
CATEdRal Tomada: Revista de crítica literaria latinoamericana / Journal of Latin American Literary Criticism No limiar da aurora: itinerários de uma travessia ritualística e alquímica em a Cidade Sitiada.

Interessante ressaltar que, a busca por essa luz que é sinônimo de epifania, conhecimento e transformação para Lucrécia, indica também que o mistério pode (tal vez) ser revelado. Quando a personagem-protagonista necessita de sol e chuva, compreendemos que essas metáforas traduzem-se em fogo e água (calcinatio e solutio), símbolos de opostos alquímicos que têm o objetivo de produzir o óleo, ou seja, este é a tintura, o ouro e a alma, o elemento unificador semelhante à Pedra Filosofal.

O símbolo da estátua associada à Lucrécia reforça que ela está vivendo o estágio liminar de seu ritual, ela espia sem entender e reconhece que muito tempo havia se passado e como um animal em busca de sua caça, ela sentia fome, mas “dagora em diante talvez não tivesse nada mais a perder. Agora seria tarde demais mesmo para morrer. Sorrindo, bonitinha, olhando a mão direita onde queria ver em breve um anel de compromisso. Mas que compromisso, de aliança” (Lispector 114).

Agregar-se ao outro (coniunctio na alquimia) e conhecer o seu mundo é começar uma viagem em direção ao interior de si mesmo, da união de uma individualidade a outra, formando-se uma unidade, o que assinala a sua constituição, a partir da experiência e amadurecimento, a fim de encontrar no outro a resposta a sua própria existência. Essa é a jornada de Lucrécia, cujo desfecho é a união com os homens que se identifica, naquele momento, percebidos sendo seu porto seguro.

Nesse sentido, Lucrécia decide viver o seu rito de agregação, em especial quando foi com um amigo de Mateus tratar dos papéis de seu casamento. Mateus é um advogado. No romance ele nos é apresentado usando bigode e chapéu de abas largas e tem como mania deixar a unha do dedo mindinho crescer. Era servil e dominador. Os preparativos para celebrar o ritual do casamento entre a protagonista e Mateus começa quando "Lucrécia estava toda enfeitada. Ana a ajudara a se vestir soluçando - enquanto ela mesma ainda guardava um sentimento para começar só nas núpcias, um sentimento que não sabia iniciar e já era quase tempo..." (Lispector 116). Esse momento solene e especial na vida da 
personagem estabelece que "as coisas novas é que a olhavam e ela passava entre elas correndo atrás do advogado. [...] Tornou-se solene, aceitou com uma reverência de cabeça, censurando-se por distrair-se em tais momentos. Estava contente de iniciar desde já o ritual da nova vida [...]" (117).

A terceira e última fase ritual, nomeada de agregação (incorporação ou reintegração), consiste na adequação da protagonista à realidade cotidiana nutrida da força ritualística, uma vez que, ao passar pelo período liminar e marginal do processo de ritualização, a personagem Lucrécia conheceu pontos de divisão, ruptura, reflexão, de cada estágio vivenciado em sua travessia e transição. $\mathrm{O}$ acesso à dimensão ritual a habilitou a assumir seu novo papel, por compreender de outra forma à vida em comunidade. A eficiência nas mudanças de estado em uma sociedade está intrinsecamente conectada à compreensão de sua estrutura ritual e a existência de uma vivência integral dos momentos de passagem.

Essa nova fase na vida de Lucrécia relacionada ao rito de agregação tem significação coletiva. Isso porque ela está ligada a Mateus, onde a aliança é o elemento simbólico que os une e os faz assumir uma nova posição social, o de casados.

O elemento unificador do casal Lucrécia e Mateus deveria ser o amor, porém não é o que acontece e, por isso a personagem percebe que poderá amar outro homem. O seu relacionamento com Mateus está desmoronando e ele é acometido por uma doença. Nas últimas viagens de Mateus, Lucrécia o acompanha a uma ilha isolada, pois a pedido dele, ela deveria engordar e manter o mesmo apetite de quando casaram, o que revela uma tentativa de Mateus em não aceitar que o rito de separação se instalasse entre eles.

A estadia da protagonista na ilha favorece certas mudanças de comportamento, em especial ligada ao contexto sóciocultural em que se vê inserida. Ela encontra na ilha, o consultório do médico Lucas. Ele é casado, mas sua esposa se encontrava no hospício e, às vezes, ele acompanha Lucrécia em passeios. 
CATEDRAL TOMADA: Revista de crítica literaria latinoamericana / Journal of Latin American Literary Criticism No limiar da aurora: itinerários de uma travessia ritualística e alquímica em a Cidade Sitiada.

Lucrécia agrega-se novamente a uma nova situação de vida, o médico acende nela aquilo que estava adormecido e obscuro, pois "quando ele foi auxiliála a vestir o casaco [...] teria ele feito mais vivos os braços? teria percebido? ou ela inventava? de incerteza a luz brumosa de um poste se acendeu, o instante se dourando na noite [...]" (Lispector 150).

A coniunctio do casal tem no símbolo da água (solutio) o elemento fertilizante e fecundo, porque "na noite que o mar enchia de sal, mas nada chegava ao próprio fim, a brisa trazia e levava as palavras e os postes se deformavam na água" (150).

Lucrécia tem na pessoa de Lucas, o início de uma nova ordem que poderia se instalar em sua vida. A sua percepção das coisas e de São Geraldo se mostravam sempre em dualidade (claro/ escuro) e, a partir de então, ele seria a luz que a guiaria em sua escuridão: "desta vez o doutor olhou-a através do escuro. Ela se ruborizou. Mas ele a olhava também com compreensão e força, guiando-a já com uma primeira dureza através da estrada escura, e evitando tocá-la" (151).

A alquimia do amor entre Lucrécia e Lucas acontece quando estão próximos do mar. Iluminava-se então a escuridão da noite:

Depois entrou em casa e acendeu a luz. No interior tudo estava leve, soprado. A cama, a mesa, a lamparina. Nada se podia tocar - as extremidades ligeiras e direitas ao vento. [...] Uma alegria mansa já começava a circular no sangue com o primeiro calor, os dentes iam de novo se aguçando e as unhas endurecendo, o coração afinal se precisando em pancadas duras e pequenas. (Lispector 152)

O amor de Lucrécia pelo médico representa um caminho de encontro consigo mesma, é como se ela estivesse enferma ou andando pelo mundo com os olhos vendados e a presença dele fosse sua salvação e também uma mão para guiá-la pelos caminhos desconhecidos. 
Viver a coniunctio para Lucrécia é um processo contínuo de unir-se a Lucas, seja na intimidade ou na relação sóciocultural. O binômio homem/ mulher nesse caso está ligado à figura do rei e da rainha, do sol e da lua, ou seja, é uma projeção simbólica que está associada ao funcionamento da psique, revelando um padrão de relacionamento entre dois ou mais fatores inconscientes. Isso acontece devido à coniunctio simbolizar processos psíquicos e, portanto, o renascimento e a transformação são componentes da psique. A coniunctio representa dois pólos, um positivo e o outro negativo e esse resultado decorre da experiência ritual e alquímica diante da matéria, que é a própria vida. Quando ocorre o rito de separação em que há "morte" e, consequentemente perda, também há o renascimento, ambos são inerentes à experiência. Trazê-los à consciência implica uma redenção de uma parte anteriormente inconsciente da personalidade.

Portanto, a visão de Lucrécia não só é estrangeira a si, como também se situa num mundo estrangeiro. O paradoxo, nesse caso, está em ser o caminho escolhido, a fim de engendrar uma intimidade com o mundo e, a partir dele, instituir que todos nós somos feitos do mesmo estofo, da mesma matéria, somos “adubos" da terra, na formação de uma cidade sempre sitiada.

Por fim, encerramos o círculo e retornamos a nossa reflexão inicial, segundo a qual, em A cidade sitiada, a terra é dura, porém fecunda. De certa forma, a relação tecida e construída pela protagonista através do olhar e da memória é movida por uma sensibilidade inata ao observar os objetos, a cidade, as pessoas, buscando traçar um caminho em que ela se depara com esse outro e o convida a entrar, em sua casa. Não pretendemos, aqui, esgotar um tema tão vasto, nossa intenção foi apenas apresentar algumas reflexões e indagações, que visam identificar possíveis enfoques interpretativos do exercício tão fascinante que é dos ritos de passagem e da alquimia. 
CATEDRAL TOMADA: Revista de crítica literaria latinoamericana / Journal of Latin American Literary Criticism No limiar da aurora: itinerários de uma travessia ritualística e alquímica em a Cidade Sitiada.

\section{Referências}

Chaui, Marilena. "Janela da alma, espelho do mundo". In: Novaes, Adauto (Org.) O olhar. São Paulo: Companhia das Letras, 1988. p. 31-63.

DaMatta, Roberto. Apresentação. Os ritos de passagem. Trad. Mariano Ferreira. 2. ed. Petrópolis, RJ: Vozes, 2011.

DaMatta, Roberto. Carnavais, malandros e heróis: para uma sociologia do dilema brasileiro. 6. ed. Rio de Janeiro: Rocco, 1997.

Douglas, M. Pureza e perigo. São Paulo: Perspectiva, 1976.

Edinger, Edward F. Anatomia da psique. Trad. Adail Ubirajara Sobral, Maria Stela Gonçalves. São Paulo: Cultrix, 1985.

Eliade, Mircea. Ferreiros e Alquimistas. Rio de Janeiro: Zahar, 1979. . Mito do eterno retorno. Trad. José Antonio Ceschin. São Paulo: Mercuryo, 1992.

Gennep, Arnold Van. Os ritos de passagem. Trad. Mariano Ferreira. 2. ed. Petrópolis, RJ: Vozes, 2011.

Jung, Carl Gustav. “As Etapas da Vida Humana”. Obras Completas. Vol. VIII. Petrópolis: Vozes, 1984. . Mysterium Coniunctionis. Vol. XIV/ I. Petrópolis, RJ: Vozes, 1988. . Os arquétipos e o inconsciente coletivo. Trad. Maria Luisa Appy; Dora Mariana R. F. S. Petrópolis: Vozes, 2000.

Kristeva, Júlia. Estrangeiros para nós mesmos. Trad. Maria Carlota Carvalho Gomes. Rio de Janeiro: Rocco, 1994.

Lispector, Clarice. A cidade sitiada. 4. ed. Rio de Janeiro: José Olympio, 1975.

Veloso, Rodrigo Felipe. Os ritos de passagem pelo coração selvagem da vida: um estudo de Perto do coração selvagem, de Clarice Lispector. Minas Gerais MG, 2012. Montes Claros: Unimontes, 2012.

Veloso, Rodrigo Felipe. "Sal da terra, luz do mundo”, ritos de passagem e alquimia: caminhos de transformação em Clarice Lispector. Minas Gerais MG, 2016. Juiz de Fora: UFJF, 2016. 